\title{
Pemberdayaan Masyarakat Desa Banjarsari Kecamatan Manyar Kabupaten Gresik Melalui Usaha Mikro Kecil Dan Menengah Di Era New Normal
}

\author{
Ferry Hariawan ${ }^{1}$, Ch. Menuk Sri Handayani ${ }^{2}$, Untung Lasiyono ${ }^{3}$, Widiar Onny \\ Kurniawan $^{4}$, Yuli Kurnia Firdausia ${ }^{5}$ \\ ${ }^{12}$ Program Studi Manajemen, Fakultas Ekonomi dan Bisnis, Universitas PGRI Adi Buana Surabaya \\ ${ }^{345}$ Program Studi Akuntansi, Fakultas Ekonomi dan Bisnis, Universitas PGRI Adi Buana Surabaya \\ e-mail koresponden: ferry@unipasby.ac.id
}

\begin{abstract}
ABSTRAK
Potensi di pedasaan merupakan sumber daya utama pembangunan desa. Kehadiran Usaha Mikro Kecil dan Menengah (UMKM) merupakan salah satu jalan untuk memfasilitasi warga desa menyalurkan potensinya dalam upaya meningkatkan kesejahteraan keluarga. Warga Desa Banjarsari Kecamatan Manyar Kabupaten Gresik berharap agar potensi desa ini dapat dikelola dengan baik dan memanfaatkan desa wisata sebagai mata pencaharian baru bagi warganya. Peluang yang ada saat ini adalah dengan membuka Usaha Mikro Kecil Menengah (UMKM) di sekitar tempat wisata tersebut. Banyak diantara warga yang bingung untuk memulai usaha terlebih di era new normal. Kondisi tersebut menunjukkan potensi yang menarik sekaligus terdapat tantangan didalamnya. Dimana kondisi masyarakat Desa Banjarsari Kecamatan Manyar Kabupaten Gresik masih membutuhkan penguatan di bidang (1) pengetahuan dan ketrampilan (skill) dalam menguasai teknologi, (2) produktivitas masyarakat dan (3) terbatasnya sarana dan prasarana. Hal ini berakibat pada rendahnya kesejahteraan masyarakat dan partisipasinya dalam pembangunan perekonomian desa.

Mendapati kondisi yang seperti itu, tim pengabdian pada masyarakat fakultas ekonomi dan bisnis universitas PGRI adi buana Surabaya memberikan penyuluhan dan pendampingan pada Usaha Mikro Kecil Menengah (UMKM) di Desa Banjarsari Kecamatan Manyar Kabupaten Gresik. Pendampingan tersebut di tujukan untuk penggerak UMKM dengan memberdayakan hasil alam sekitar dan membuat produk baru/tambahan yang relevan dengan kondisi kebutuhan dan perilaku pasar di masa new normal ini.
\end{abstract}

Kata Kunci: Pengabdian pada masyarakat, UMKM, New Normal

\section{ABSTRACT}

The potential in this village is the main resource for village development. The presence of Micro, Small and Medium Enterprises (MSMEs) is one way to facilitate villagers to channel their potential in an effort to improve family welfare. The residents of Banjarsari Village, Manyar District, Gresik Regency, hope that the potential of this village can be managed properly and take advantage of the tourist village as a new livelihood for its residents. The current opportunity is to open a Micro, Small and Medium Enterprise (MSMEs) around these tourist attractions. Many of the residents are confused about starting a business, especially in the new normal era. This condition shows an interesting potential as well as there are challenges in it. Where the condition of the people of Banjarsari Village, Manyar District, Gresik Regency, still needs strengthening in the fields of (1) knowledge and skills in mastering technology, (2) community productivity 
and (3) limited facilities and infrastructure. This results in low community welfare and participation in village economic development.

Finding such conditions, the community service team at the faculty of economics and business, PGRI Adi Buana University, Surabaya provided counseling and assistance to Micro, Small and Medium Enterprises (MSMEs) in Banjarsari Village, Manyar District, Gresik Regency. The assistance is aimed at activating MSMEs by empowering the surrounding natural products and making new / additional products that are relevant to the conditions of market needs and behavior in this new normal period.

Keywords: Community service, MSMEs, New Normal 


\section{PENDAHULUAN}

Pandemi Covid-19 telah menggangu berbagai sektor. Berbagai sektor juga terkena dampaknya, dari pelaku industri besar hingga usaha mikro, kecil, dan menengah (UMKM). Transformasi dunia bisnis yang tak terhindarkan. Tak terkecuali di sektor UMKM. Pemerintah pusat dan daerah telah mengeluarkan berbagai kebijakan untuk mengurangi penyebaran virus melalui physical distancing, mulai dari Pembatasan Sosial Berskala Besar hingga penerapan new normal. dampaknya, terdapat pengurangan interaksi sosial langsung dari pusat keramaian, seperti tempat ibadah, sekolah, pusat perbelanjaan, tempat hiburan, restoran, dan angkutan umum.

UMKM memiliki peran yang sangat penting dalam pertumbuhan perekonomian Indonesia, memainkan peran yang sangat berpotensi dalam menciptakan ragam pasar baru, meningkatkan suplay, meningkatkan persaingan, mengembangkan teknologi, meningkatkan kesempatan kerja dan hasil produksi. Potensi di pedasaan ini merupakan sumber daya utama pembangunan desa. Kehadiran Usaha Mikro Kecil dan Menengah (UMKM) merupakan salah satu jalan untuk memfasilitasi warga desa menyalurkan potensinya dalam upaya meningkatkan kesejahteraan keluarga.

Usaha Mikro Kecil Menengah (UMKM) berperan penting dalam mendorong pemerataan kesejahteraan masyarakat dan menjadi tulang punggung perekonomian Indonesia. (Vera et al, 2018).

Terabaikannya potensi masyarakat ini akan meyebabkan ancaman serius bagi perekonomian negara. Selain kemiskinan, ancaman serius datang dari ketahanan pangan, karena pedesaan identik dengan sumber pangan masyarakat.

Keberadaan UMKM terbukti mampu menjadi penyelamat perekonomian, khususnya di Indonesia. Sektor UMKM menyerap 97.22\% tenaga kerja dari pelaku usaha nasional. Kontribusi yang diberikan UMKM diharapkan akan berlanjut dengan cara pemerintah dan pihak-pihak yang terkait memiliki acuan yang jelas mengenai faktorfaktor yang mempengaruhi keberhasilan usaha (Kemenperin 2016). Perkembangan dunia usaha yang semakin meningkat selaras dengan peningkatan kondisi perekonomian di Indonesia juga berarti adanya persaingan yang semakin ketat. Sebagian besar perusahaan memiliki tujuan yang sama yakni berorientasi untuk mendapatkan sejumlah laba semaksimal mungkin meskipun disamping misi-misi lainnya (Khusnul 2016).

Dengan melihat peluang dan kontribusi serta kenyataan yang ada peran UMKM terhadap perekonomian, maka maka dipandang perlu adanya grand strategy pengembangan melalui pemberdayaan UMKM yang menjadi sumber pertumbuhan baru perekonomian Indonesia. (Renstra Kemenkop RI: 2012).

Berangkat dari analisis keadaan desa mitra tersebut, kami mengusung program kegiatan pelatihan Pemberdayaan Masyarakat Desa Banjarsari Kecamatan Manyar Kabupaten Gresik Melalui Usaha Mikro Kecil dan Menengah di Era New Normal. Maksud dari tim pengabdian masyarakat ini adalah menanamkan kepada masyarakat bahwasannya mereka memiliki sumber daya dan segala potensi yang ada didesa yang dapat dikembangkan. Menumbuhkan jiwa kewirausahaan sangat penting karena akan menumbuhkan masyarakat yang berdikari dan produktif. Dengan pelatihan kewirausahan 
UMKM ini, masyarakat yang belum punya pekerjaan terdorong untuk menciptakan pekerjaan. Adapun bagi masyarakat yang sudah memiliki pekerjaan, hasil usaha menjadi berlipat ganda. Kontribusi dan peran UMKM di Indonesia yang strategis ternyata masih dihadapkan pada berbagai permasalahan (Santi, Pramestika Era 2017)

Dengan demikian Tim Pengabdian Pada Masyarakat melaksanaan Pengabdian Masyarakat Program Studi Manajemen Fakultas Ekonomi dan Bisnis Universitas PGRI Adi Buana Surabaya Tahun Akademik 2019 - 2020 tepatnya di wilayah Desa Banjarsari Kecamatan Manyar Kabupaten Gresik dan mengajukan kegiatan pengabdian pada masyarakat dengan judul "Pemberdayaan Masyarakat Desa Banjarsari Kecamatan Manyar Kabupaten Gresik Melalui Usaha Mikro Kecil dan Menengah di Era New Normal" dengan harapan dapat memberikan jalan keluar mengenai permasalahan yang dihadapi oleh masyarakat sehingga dapat meningkatkan kesejahteraannya.

\section{METODE PELAKSANAAN}

Persoalan yang dihadapi oleh mitra adalah kurangnya pengetahuan mengenai manajemen kewirausahaan, sehingga tim memberikan solusi dengan memberikan penyuluhan. Metode pelaksanaan kegiatan pengabdian ini antara lain :

1. Penyuluhan

Metode penyuluhan yang dilakukan dalam kegiatan pengabdian ini adalah ceramah. Tim pengabdian memberikan pemahaman kepada mitra terkait dengan Pemberdayaan Masyarakat Desa Banjarsari Kecamatan Manyar Kabupaten Gresik Melalui Usaha Mikro Kecil dan Menengah di Era New Normal.

\section{Pendampingan}

Tahap kedua yang dilakukan oleh tim pengabdian yaitu pendampingan kepada mitra Desa Banjarsari Kecamatan Manyar Kabupaten Gresik. Pendampingan dilakukan oleh tim pengabdian untuk mengetahui keberhasilan program yang ditawarkan oleh tim maka dilakukan diskusi antara tim dengan mitra. Hal ini dilakukan untuk mengetahui hambatan-hambatan yang dialami oleh mitra selama melakukan proses pendampingan sehingga tim dapat memberikan solusi kepada mitra.

\section{Evaluasi Pelaksanaan}

Evaluasi dirancang dengan melakukan monitoring dengan pertemuan kembali pasca penyuluhan. Dalam monitoring ini akan didiskusikan tentang berbagai hal yang mereka alami pasca pelatihan. Berbagai masalah mungkin sekali muncul, dan pada saat itulah ditawarkan berbagai alternatif pemecahan.

\section{HASIL DAN PEMBAHASAN}

Desa Banjarsari secara geografis terletak di wilayah Kecamatan Manyar Kabupaten Gresik. Beberapa wilayah kecamatan Manyar banyak penduduk yang bermatapencaharian sebagai pedagang, petani dan pekerja. Desa Banjarsari Kecamatan Manyar Kabupaten Gresik merupakan desa yang sudah cukup maju. Saat ini warga Desa Banjarsari Kecamatan Manyar sedang membangun desa mereka sebagai desa wisata. Lokasi wisata berada tidak jauh dari pemukiman warga. Kepala Desa Banjarsari 
Kecamatan Manyar Kabupaten Gresik berharap agar potensi desa ini dapat dikelola dengan baik dan memanfaatkan desa wisata sebagai mata pencaharian baru bagi warganya. Peluang yang ada saat ini adalah dengan membuka Usaha Mikro Kecil Menengah (UMKM) di sekitar tempat wisata tersebut.

Warga Desa Banjarsari Kecamatan Manyar Kabupaten Gresik ternyata belum memiliki kesiapan untuk menyambut desa wisata ini. Banyak diantara warga yang bingung untuk memulai usaha terlebih di era new normal. Kondisi tersebut menunjukkan potensi yang menarik sekaligus terdapat tantangan didalamnya. Dimana kondisi masyarakat Desa Banjarsari Kecamatan Manyar Kabupaten Gresik masih membutuhkan penguatan di bidang (1) pengetahuan dan ketrampilan ( $k$ kill) dalam menguasai teknologi, (2) produktivitas masyarakat dan (3) terbatasnya sarana dan prasarana. Hal ini berakibat pada rendahnya kesejahteraan masyarakat dan partisipasinya dalam pembangunan perekonomian desa.

Mendapati kondisi yang seperti itu, tim pengabdian pada masyarakat program studi manajemen fakultas ekonomi dan bisnis universitas PGRI adi buana Surabaya memberikan penyuluhan dan pendampingan pada Usaha Mikro Kecil Menengah (UMKM) di Desa Banjarsari Kecamatan Manyar Kabupaten Gresik. Pendampingan tersebut di tujukan untuk penggerak UMKM dengan memberdayakan hasil alam sekitar dan membuat produk baru/tambahan yang relevan dengan kondisi kebutuhan dan perilaku pasar di masa new normal ini.

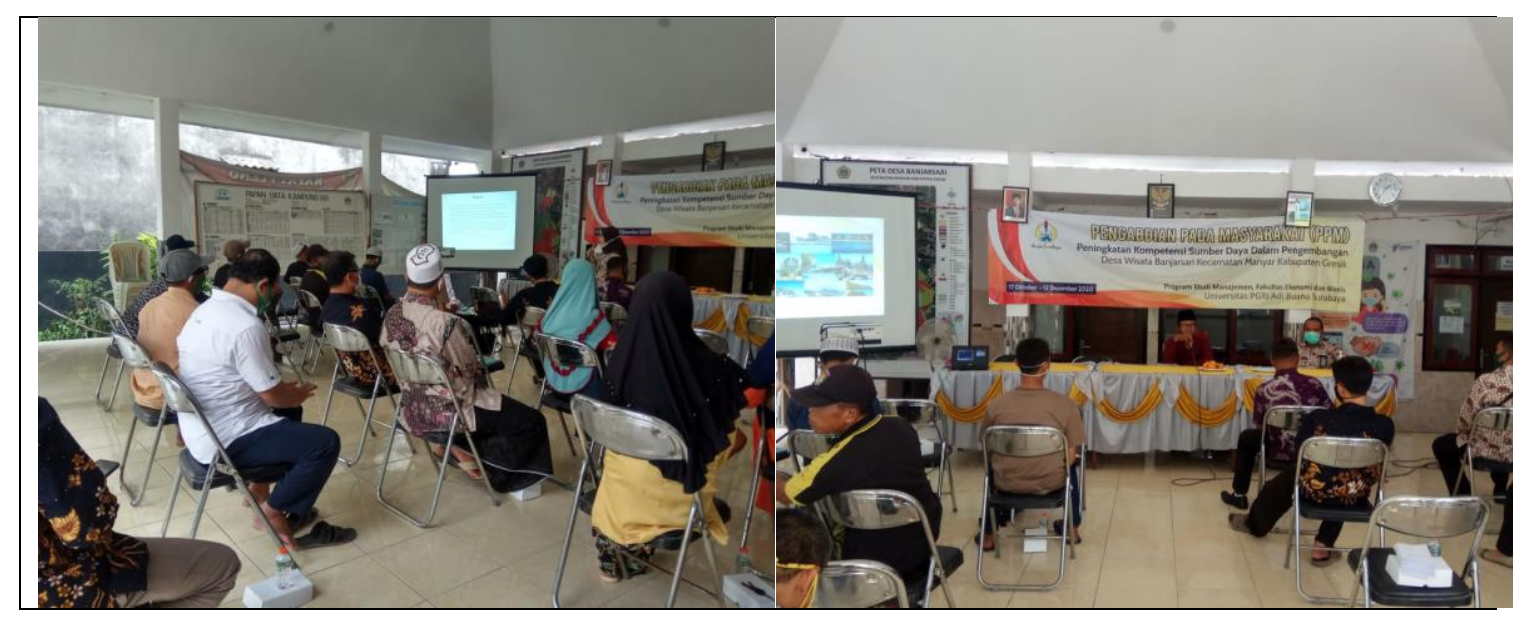

Gambar 1

Tim Penyuluhan Pengabdian Masyarakat

\section{DAMPAK MANFAAT KEGIATAN}

Aktivitas penyuluhan pada Desa Banjarsari Kecamatan Manyar Kabupaten Gresik ini dihadiri oleh warga yang terdiri dari para pelaku Usaha Mikro Kecil Menengah (UMKM). Selama pelaksanaan, peserta cukup antusias dan aktif dalam melakukan diskusi dan tanya jawab mengenai materi-materi yang disampaikan. Warga Desa 
Banjarsari Kecamatan Manyar Kabupaten Gresik tertarik dengan jenis usaha pengolahan makanan. Olahan makanan dirasa cukup mudah dan memiliki banyak rasa, jenis dan bentuk.

Manfaat Pengabdian pada Masyarakat di Desa Banjarsari Kecamatan Manyar Kabupaten Gresik telah memberikan dukungan kepada masyarakat mengenai pemberdayaan melalui usaha mikro kecil dan menengah di era new normal. Pemberdayaan tersebut lebih di fokuskan kepada pemanfaatan hasil alam yang di hasilkan oleh masyarakat itu sendiri.

\section{SIMPULAN}

Pelaku Usaha Mikro Kecil Menengah (UMKM) di Desa Banjarsari Kecamatan Manyar Kabupaten Gresik, Setelah dilakukannya penyuluhan dan pendampingan terdapat semangat dan harapan baru di era new normal ini. Masyarakat menjadi lebih memahami kebutuhan apa saja yang dibutuhkan oleh masyarakat sehingga produk yang ditawarkan dapat dijual dengan baik.

\section{UCAPAN TERIMA KASIH}

Tim pengabdian Fakultas Ekonomi Bisnis mengucapkan terima kasih atas pendanaan internal dari Lembaga Penelitian dan Pengabdian Masyarakat Universitas PGRI Adi Buana Surabaya yang telah diberikan kepada tim Pengabdian, sehingga program-program yang ditawarkan oleh tim kepada mitra berjalan dengan lancar serta mitra dapat memperoleh manfaat atas program yang ditawarkan yang dilakukan oleh tim pengabdian.

\section{DAFTAR PUSTAKA}

Adisasmita, Rahardjo. (2013). Pembangunan Perdesaan: Pendekatan Partisipatif, Tipologi, Strategi, Konsep Desa Pusat Pertumbuhan. Yogyakarta, Graha Ilmu.

Afkar, Taudlikhul. (2016). Penganggaran Bisnis. Surabaya: Adi Buana University Press Afkar, Taudlikhul. (2016). Efektivitas Pengendalian Preventif, Pengendalian Detektif, Dan Pengendalian Represif Terhadap Pencegahan Kecurangan Akuntansi. Majalah Ekonomi. Volume 2, Nomor 2. Desember). Hal 211-225

Afkar, Taudlikhul., Waryanto, R. Bambang Dwi., Istikhoroh, Siti., Subakir., Sugijanto., Fauziyah. 2018. Upaya Peningkatan Penghasilan Ukm Dengan Tertib Administrasi Keuangan Di Desa Kenongo Kecamatan Tulangan Sidoarjo. AJIE - Asian Journal of Innovation and Entrepreneurship. e-ISSN: 2477-0574; p-ISSN: 2477-3824. Vol. 03, Issue. 03, September 2018

Antara. (2020, Agustus 9). Antara News. Retrieved from antaranews.com: https://www.antaranews.com/berita/1621166/mendes-pdtt-10026-bumdes-masihtetap-bertahan-ditengah-pandemi

Bupati Gresik Provinsi Jawa Timur. (2017). Peraturan Daerah Kabupaten Gresik Nomor 3 Tahun 2017 Tentang Badan Usaha Milik Desa. Gresik: Bupati Gresik Provinsi Jawa Timur. 
Deegan, M., \& Tanner, S. (2002). Digital Futures: Strategies for the Information Age Volume 1 of Digital futures series Library and Information Studies. United States: Neal-Schuman Publishers.

Feather, N. T. (1996). Reaction to Penalties for an Offense in Relation to Autoritarianism, Values, Perceived Responsibility, Perceived Seriousness and Deservigness. Journal of Personality and Social Psychology. 71. pp 571-587.

Kabupaten Gresik. (2020, Agustus 8). Kabupaten Gresik. Retrieved from gresikkab.go.id: https://gresikkab.go.id/division/

Sawitri, A. P., Afkar, T., Suhardiyah, M., \& Suharyanto. (2020). Penguatan Pengelolaan Keuangan BUMDes Sebagai Upaya Menuju Desa Mandiri di Desa Kebontunggul Mojokerto. JPM (Jurnal Pemberdayaan Masyarakat). 5(2). https://doi.org/10.21067/jpm.v5i2.4324

Sujarweni, V. Wiratna. (2014). Akuntansi Desa, Pustaka Baru.

Titioka, Baretha M., Huliselan, Meny., Sanduan, Abdullah., Ralahallo, Fransiska N., Astrid Siahainenia, J.D. (2020). Pengelolaan Keuangan Bumdes Di Kabupaten Kepulauan Aru. Jurnal Pengabdian Masyarakat Jamak (Manajemen \& Akuntansi). Vol 03. No. 01, Juni 2020197 | p-ISSN: 2654-7317; e-ISSN: 2656-7970 